\title{
Conservation and Loss of Ribosomal RNA Gene Sites in Diploid and Polyploid Fragaria (Rosaceae)
}

\author{
Bo Liu and Thomas M Davis
}

\begin{abstract}
Background: The genus Fragaria comprises species at ploidy levels ranging from diploid $(2 n=2 x=14)$ to decaploid $(2 n=10 x=70)$. Fluorescence in situ hybridization with $5 S$ and $25 S$ rDNA probes was performed to gather cytogenetic information that illuminates genomic divergence among different taxa at multiple ploidy levels, as well as to explore the evolution of ribosomal RNA genes during polyploidization in Fragaria.

Results: Root tip cells of diploid taxa were typified by two 55 and six 255 rDNA hybridization signals of varying intensities, providing a baseline for comparisons within the genus. In three exceptional diploid genotypes, $F$. nilgerrensis (CFRA 1358 and CFRA 1825) and F. vesca 'Yellow Wonder', two 5S but only four 25S rDNA sites were found but with differing site losses. The numbers of $5 \mathrm{~S}$ and $25 \mathrm{~S}$ rDNA signals, respectively were three and nine in a triploid F. $\times$ bifera accession, and were four and twelve in three tetraploids, thus occurring in proportional $1.5 \times$ and $2 \times$ multiples of the typical diploid pattern. In hexaploid F. moschata, a proportional multiple of six 5S rDNA sites was observed, but the number of $25 \mathrm{~S}$ rDNA sites was one or two less than the proportionate prediction of eighteen. This apparent tendency toward rDNA site loss at higher ploidy was markedly expanded in octoploids, which displayed only two $5 \mathrm{~S}$ and ten $25 \mathrm{~S}$ rDNA sites. In the two decaploids examined, the numbers of $5 \mathrm{~S}$ and $25 \mathrm{~S}$ rDNA signals, respectively, were four and fifteen in F. virginiana subsp. platypetala, and six and twelve in $F$. iturupensis.

Conclusions: Among diploid Fragaria species, a general consistency of rDNA site numbers implies conserved genomic organization, but highly variable $25 \mathrm{~S}$ signal sizes and intensities and two instances of site loss suggest concurrent high dynamics of rDNA copy numbers among both homologs and non-homologs. General conservation of rDNA site numbers in lower ploidy, but marked site number reductions at higher ploidy levels, suggest complex evolution of rDNA sites during polyploidization and/or independent evolutionary pathways for $6 x$ versus higher ploidy strawberries. Site number comparisons suggest common genomic composition among natural octoploids, and independent origins of the two divergent decaploid accessions.
\end{abstract}

\section{Background}

The strawberry genus Fragaria belongs to the Rosaceae, an economically important plant family, and includes about 24 species distributed mostly throughout the temperate zone of Europe, Asia, North and South America $[1,2]$. Historically, a basic chromosome number of seven $(x=7)$ and the existence of multiple levels of ploidy, ranging from diploid to octoploid, in this genus had been documented by 1926 [3,4]. Only recently, a naturally occurring decaploid cytotype $(2 n=10 x=70)$ was revealed through chromosome counting and flow

\footnotetext{
* Correspondence: tom.davis@unh.edu

* Correspondence: tom.davis@unh.edu
Department of Biological Sciences, University of New Hampshire, Durham, $\mathrm{NH}$ 03824, USA
} NH 03824, USA

cytometry [5] in the geographically isolated species $F$. iturupensis, which had initially been described as an octoploid $(2 n=8 x=56)$ [6]. In addition, an accession (CFRA 110) of $F$. virginiana subsp. platypetala has been found by chromosome counting to be decaploid [7]. Currently, twelve diploid $(2 n=2 x=14)$, five tetraploid $(2 n=4 x=28)$, a single hexaploid $(2 n=6 x=42) F$. moschata, three octoploid $(2 n=8 x=56)$ species, including the main cultivated species $F$. xananassa and its immediate octoploid ancestors: F. chiloensis and $F$. virginiana [8], and a decaploid $(2 n=10 x=70) F$. iturupensis are recognized $[1,5,9,10]$. In addition, variableand odd-ploidy have been recognized in two hybrid taxa: pentaploid/hexaploid/enneaploid $(2 n=5 x / 6 x / 9 x=$ 
35/42/63) F. xbringhurstii [11] and diploid/triploid $(2 n=$ $2 x / 3 x=14 / 21) F . \times$ bifera [12]. The higher level $(>4 x)$ polyploids are all considered to have at least partially allopolyploid genome compositions; however, classifications of origins as auto- or allo-ploidy have not been resolved at the tetraploid level [13].

Non-isotopic in situ hybridization (ISH) was introduced in plants in 1985 [14], and fluorescence-based techniques (FISH) have subsequently become routine methods for physical mapping of repetitive DNA sequences and multicopy gene families [15] and other DNA sequences onto chromosomes [16], as well as for the identification of individual chromosomes (e.g., [17]). Ribosomal RNA (rRNA) genes have been the most widely targeted probe sites due to their high copy numbers, specific chromosomal positions and the high degree of sequence conservation among different plant groups $[18,19]$. In eukaryotes, including higher plants, nuclear $18 \mathrm{~S}, 5.8 \mathrm{~S}$ and $25 / 28 \mathrm{~S}$ rRNAs (25S in plants; $28 \mathrm{~S}$ in mammals) [20,21] result from processing of a $45 \mathrm{~S}$ transcript encoded by rDNA repeated units clustered at particular chromosomal sites. The $5 \mathrm{~S}$ rRNA results from transcription of distinct gene clusters located in different chromosomal sites [22].

Previous reports on cytogenetics in strawberry are mostly limited to chromosome counting, as initiated by Ichijima [3] and Longley [4], and more recently to traditional karyotype analysis [7,23-26]. In the field of modern molecular cytogenetics, in which fluorescence in situ hybridization (FISH) techniques play a key role, work on strawberry has been minimal. Feasibility of FISH with rDNA probes was first established by Lim [27] in diploid strawberry, with confirmation by Shulaev et al. [28], but the technique has yet to be extended to the genetically and cytologically more complex genomes of the polyploid Fragaria species. As a genus that spans ploidy levels from diploid through decaploid, the genus Fragaria offers a previously untapped opportunity for studying the evolutionary changes in chromosomal rDNA arrays that have occurred during polyploidy evolution, and will contribute to ongoing efforts to define the genomic composition(s) of the polyploid strawberry species. Moreover, we anticipate that the study reported here will contribute to further development of comparative molecular cytogenetics in Rosaceae, as strawberry is one of the best-developed model organisms for this family [29].

The objectives of this work were to characterize the genomic distribution of $5 \mathrm{~S}$ and $25 \mathrm{~S}$ rDNA arrays in Fragaria species, and to assess the changes in rDNA site number that are associated with polyploidization in Fragaria.

\section{Results}

Numbers of $5 \mathrm{~S}$ and 25S rDNA sites visualized by fluorescence in situ hybridization in one or more accessions of each studied taxon are shown (Table 1). For each accession, at least five cells with good chromosome spreads and hybridization signals were observed. In all the species including the diploids and polyploids, $5 \mathrm{~S}$ rDNA sites were all localized on proximal regions of short chromosome arms, and 25S rDNA sites were all localized on terminal chromosomal regions. The site numbers of both rDNA types was consistent within each level of ploidy, with the following exceptions. As detailed below, five diploid cytotypes had less than the number of $25 \mathrm{~S}$ signals presented by the typical diploid cytotype. The intensity and size pattern of $25 \mathrm{~S}$ signals displayed variability within the diploids. Also, a difference of $25 \mathrm{~S}$ site number was observed between the two hexaploid F. moschata (CFRA 157 and CFRA 376) genotypes. Finally, the two decaploid taxa differed from each other in both $5 \mathrm{~S}$ and $25 \mathrm{~S}$ site numbers.

\section{Genomic distribution of 5 S and 25S rDNA sites in diploids} Among most diploid accessions examined, a common distribution pattern of rDNA sites was observed, involving three chromosome pairs. In this pattern (Figures 1A-1G, Figure 2A) six 25S rDNA sites were localized on three chromosome pairs, one of which was also marked by a pair of $5 \mathrm{~S}$ rDNA sites. Among these three chromosome pairs, we designated the medium-sized submetacentric pair that is "single-marked" by $25 \mathrm{~S}$ rDNA signals as the "M pair". The other two marked pairs (S1 and S2) were the smallest among the seven chromosome pairs, and were either submeta- or subtelo-centric. A pair of 25S rDNA signals was present on one of these two small chromosome pairs, hereafter referred to as the "S1 pair" (for the small-sized, "single-marked" pair), while the small, "double-marked" pair with both $25 \mathrm{~S}$ and $5 \mathrm{~S}$ sites was designated the "S2 pair" (Figure 2).

Besides the typical pattern shared by most diploid strawberries, some distinct patterns involving reduced numbers of $25 \mathrm{~S}$ sites were seen (Figure 2). The S2 pair typically carrying both $5 \mathrm{~S}$ and $25 \mathrm{~S}$ rDNA sites lacked the 25S FISH signal on both homologs in all examined cells of $F$. vesca subsp. vesca 'Yellow Wonder', leaving this accession with only four $25 \mathrm{~S}$ signals along with two $5 \mathrm{~S}$ signals (Figures $1 \mathrm{~K}$ and $2 \mathrm{C}$ ). Among the diploid accessions, only 'Yellow Wonder' did not have any chromosomes double marked by $25 \mathrm{~S}$ and $5 \mathrm{~S}$ rDNA signals (Table 1). In a parallel case, it was the typically singlemarked S1 pair that lacked the 25S FISH signal on both homologs (Figures $1 \mathrm{H}$ and $2 \mathrm{~F}$ ) in F. nilgerrensis (CFRA 1358 and CFRA 1825). Contrastingly, only one homolog of the S1 pair lacked a $25 \mathrm{~S}$ signal in all examined cells 
Table 1 Numbers of 55 and 25S rDNA sites in different Fragaria spp.

\begin{tabular}{|c|c|c|c|c|}
\hline \multirow[t]{2}{*}{ Species } & \multirow[t]{2}{*}{ Ploidy } & \multirow[t]{2}{*}{ Accession } & \multicolumn{2}{|c|}{ rDNA site number } \\
\hline & & & $5 S$ & $25 \mathrm{~S}$ \\
\hline F. bucharica & $2 x$ & CFRA 520 & $2^{*}$ & 6 \\
\hline F. daltoniana & $2 x$ & CFRA 1685 & $2^{*}$ & 6 \\
\hline F. iinumae & $2 x$ & CFRA 1850 & $2^{*}$ & 6 \\
\hline F. mandshurica & $2 x$ & CFRA 1947 & $2^{*}$ & 6 \\
\hline F. nilgerrensis & $2 x$ & CFRA 1358 & $2^{*}$ & 4 \\
\hline F. nilgerrensis & $2 x$ & CFRA 1825 & $2^{*}$ & 4 \\
\hline F. nipponica & $2 x$ & CFRA 1862 & $2^{*}$ & 5 \\
\hline F. pentaphylla & $2 x$ & GS34 & $2^{*}$ & 6 \\
\hline F. vesca ssp. americana & $2 x$ & CFRA 1948 & $\begin{array}{l}2=1^{*}+ \\
1\end{array}$ & 5 \\
\hline F. vesca ssp. americana & $2 x$ & 'WC6' & $2^{*}$ & 6 \\
\hline F. vesca ssp. bracteata & $2 x$ & 'BC32' & $2^{*}$ & 6 \\
\hline F. vesca ssp. bracteata or californica & $2 x$ & CFRA 1990 & $2^{*}$ & 6 \\
\hline F. vesca ssp. bracteata or californica & $2 x$ & 'HP6A' & $2^{*}$ & 6 \\
\hline F. vesca ssp. vesca & $2 x$ & CFRA 438 & $2^{*}$ & 6 \\
\hline F. vesca ssp. vesca & $2 x$ & 'NOV 1C' & $2^{*}$ & 6 \\
\hline F. vesca ssp. vesca & $2 x$ & 'Yellow Wonder' & 2 & 4 \\
\hline F. vesca ssp. vesca & $2 x$ & 'Hawaii 4' & $2^{*}$ & 6 \\
\hline F. viridis & $2 x$ & CFRA 333 & $2^{*}$ & 6 \\
\hline F. xbifera & $3 x$ & GS104 & $3^{*}$ & 9 \\
\hline F. corymbosa & $4 x$ & CFRA 1911 & $4^{*}$ & 12 \\
\hline F. gracilis & $4 x$ & GS31 & $4^{*}$ & 12 \\
\hline F. tibetica & $4 x$ & GS28 & $4^{*}$ & 12 \\
\hline F. moschata & $6 x$ & CFRA 157 & $6=5^{*}+1$ & 16 \\
\hline F. moschata & $6 x$ & CFRA 376 & $6=5^{*}+1$ & 17 \\
\hline F. chiloensis ssp. chiloensis f. patagonica & $8 x$ & CFRA 1100 & 2 & 10 \\
\hline F. chiloensis ssp. lucida & $8 x$ & CFRA 1691 & 2 & 10 \\
\hline F. chiloensis ssp. pacifica & $8 x$ & CFRA 48 & 2 & 10 \\
\hline F. virginiana ssp. glauca & $8 x$ & CFRA 1992 & 2 & 10 \\
\hline F. virginiana ssp. glauca & $8 x$ & CFRA 370 & 2 & 10 \\
\hline F. virginiana ssp. grayana & $8 x$ & CFRA 1408 & 2 & 10 \\
\hline F. virginiana ssp. virginiana & $8 x$ & CFRA 1994 & 2 & 10 \\
\hline F. virginiana ssp. platypetala & $10 x$ & CFRA 110 & $4=1^{*}+3$ & 15 \\
\hline F. iturupensis & $10 x$ & CFRA 1841 & 6 & 12 \\
\hline
\end{tabular}

* chromosomes bearing both $25 \mathrm{~S}$ and $5 \mathrm{~S}$ rDNA sites.

Local numbers are shown here if CFRA numbers are not available.

in F. nipponica (CFRA 1862, Figures $1 \mathrm{I}$ and 2E). Also, although six $25 \mathrm{~S}$ signals were observed in $F$. iinumae (CFRA 1850, Figure 1G), the signal on one member of the $\mathrm{S} 1$ pair was variable among cells, ranging from very small (cells 1 to 3 in Figure 2D) to extremely weak (cell 4 in Figure 2D), and to even invisible (cell 5 in Figure 2D). Finally, in F. vesca subsp. americana 'Pawtuckaway' (CFRA 1948) only one member of the S2 pair had a $25 \mathrm{~S}$ signal in 24 out of 26 cells (Figures 1J and 2B), while in the other two cells, both S2 homologs had 25S signals (e.g., cell 5 in Figure 2B).

In most diploid accessions, remarkable variability in signal size and intensity was observed among the three
$25 \mathrm{~S}$ rDNA loci as well as between homologs at each $25 \mathrm{~S}$ locus. (Figures 1 and 2). Yet of the three typically marked chromosome pairs, no one pair had consistently the brightest or least bright $25 \mathrm{~S}$ signals across the diploid accessions. For instance, in F. vesca 'Hawaii 4' the $25 \mathrm{~S}$ rDNA FISH signals on the $\mathrm{M}$ pair were remarkably smaller and weaker than the ones on the S1 and S2 pairs, thus showing a "minor M - major S1 - major S2" pattern (Figure 2A); while in F. nipponica the S1 pair showed the smallest and weakest $25 \mathrm{~S}$ rDNA signals, thus presenting a "major M - minor S1 - major S2" pattern (Figure 2E). This variability in allocation patterns of "major" and "minor" 25S rDNA signals were not only 


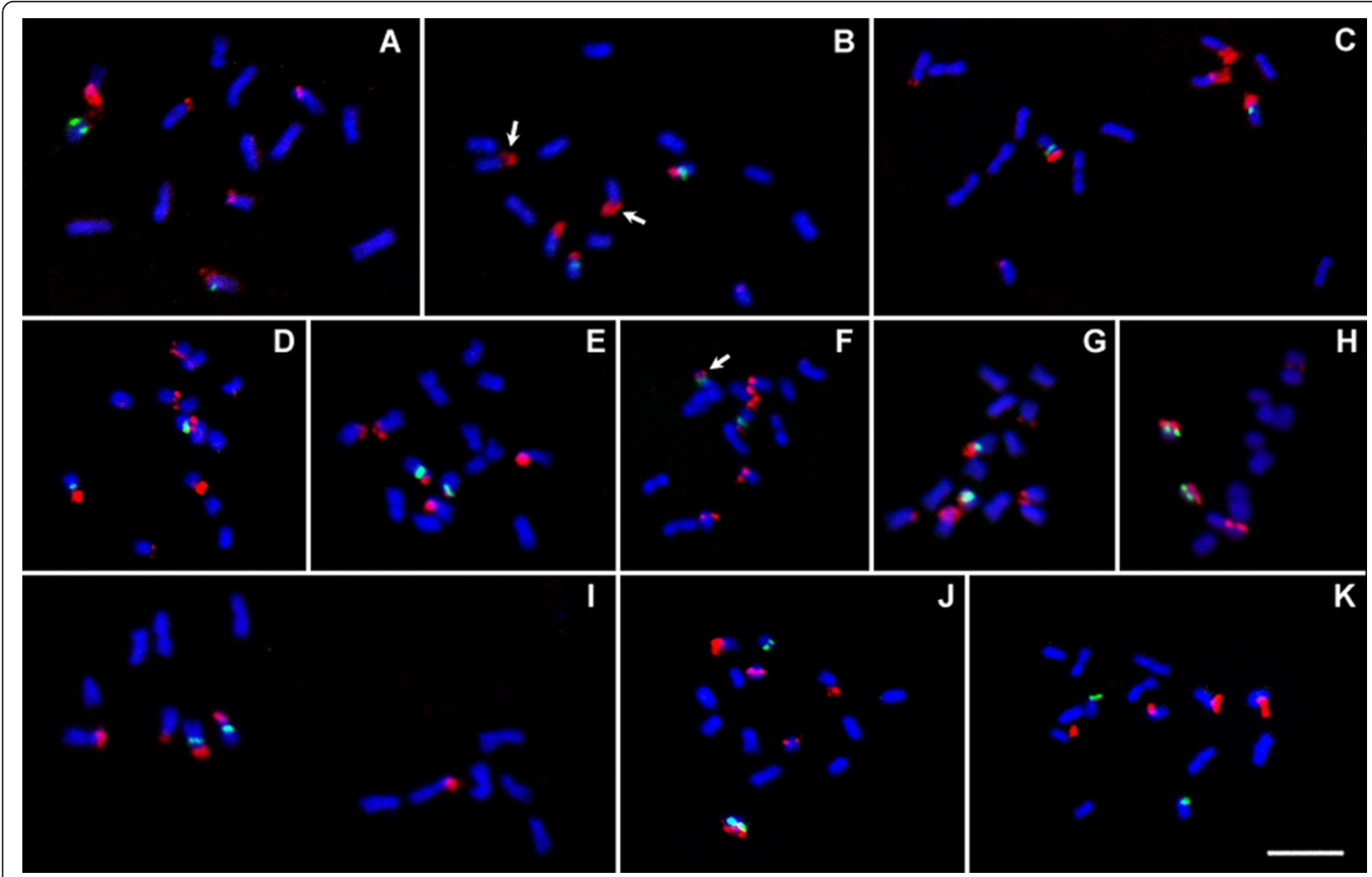

Figure 1 FISH on diploid Fragaria genotypes with 5 S (green signals) and 25 S (red signals) rDNA probes. A: $F$. bucharica (CFRA 520); B: $F$. mandshurica (CFRA 1947); C: F. vesca subsp. vesca 'Hawaii 4'; D: F. daltoniana (CFRA 1685); E: F. pentaphylla 'GS34'; F: F. viridis (CFRA 333); G: $F$. iinumae (CFRA 1850); H: F. nilgerrensis (CFRA 1358); I: F. nipponica (CFRA 1862); J: F. vesca subsp. americana 'Pawtuckaway' (CFRA 1948); K: F. vesca subsp. vesca 'Yellow Wonder'. Arrows show locations of satellites that are visible under DAPI counterstain. Bar $=5 \mu \mathrm{m}$.

observed among different diploid species but also between subspecies (e.g., "minor M - major S1 - major $\mathrm{S} 2$ ” in F. vesca subsp. vesca 'Hawaii 4' versus “major $\mathrm{M}$ - major S1 - major S2" in F. vesca subsp. americana 'Pawtuckaway', Figures 2A and 2B), or even between different accessions within a subspecies (e.g., F. vesca subsp. vesca 'Hawaii 4' versus “major M - major S1 none S2" in F. vesca subsp. vesca 'Yellow Wonder', Figures $2 \mathrm{~A}$ and $2 \mathrm{C}$ ). Within a single accession, on the other hand, the allocation patterns were generally consistent among examined cells (Figure 2). Contrastingly, one or two satellites and secondary constrictions, which are cytological markers for transcriptional active rDNA sites, are only sometimes visible in metaphase chromosome preparations in some diploids (Figure 1) and were variously associated with either "major" or "minor" FISH signals.

\section{Number of 5S and 25S rDNA sites in polyploids}

$F$. xbifera is a naturally occurring hybrid species and involves both diploid and triploid cytotypes [12]. The accession (GS104) examined in our study was a triploid as shown by chromosome counting. The numbers of $5 \mathrm{~S}$ and 25S rDNA sites in the triploid F. x bifera were three and nine, respectively (Figure 3A). Each of the three $5 \mathrm{~S}$ rDNA sites was co-localized with a 25 rDNA signal. However, one 5S rDNA signal was obviously larger and stronger than the other two.

The three tetraploid species shared the same numbers of rDNA sites, which were four for $5 \mathrm{~S}$ and twelve for $25 \mathrm{~S}$ rDNA (Figures 3B-3D). These numbers are twice the numbers of two $5 \mathrm{~S}$ and six $25 \mathrm{~S}$ sites detected in most diploids, and each of the tetraploids' $5 \mathrm{~S}$ rDNA sites was co-localized with a $25 \mathrm{~S}$ rDNA site. Although the number and position of rDNA sites was strictly consistent among the tetraploids, differences in signal size and intensity among sites were observed. In $F$. gracilis (Figure 3C) and F. tibetica (Figure 3D), 25S rDNA sites among three homologous chromosome groups were not of noticeably different signal intensities, while in F. corymbosa (CFRA 1911, Figure 3B), $25 \mathrm{~S}$ rDNA sites in one "single-marked" group of four chromosomes had larger signals than those of the other two groups. Also, among the total four $5 \mathrm{~S}$ rDNA sites in $F$. corymbosa, two were larger and stronger than the other two. 

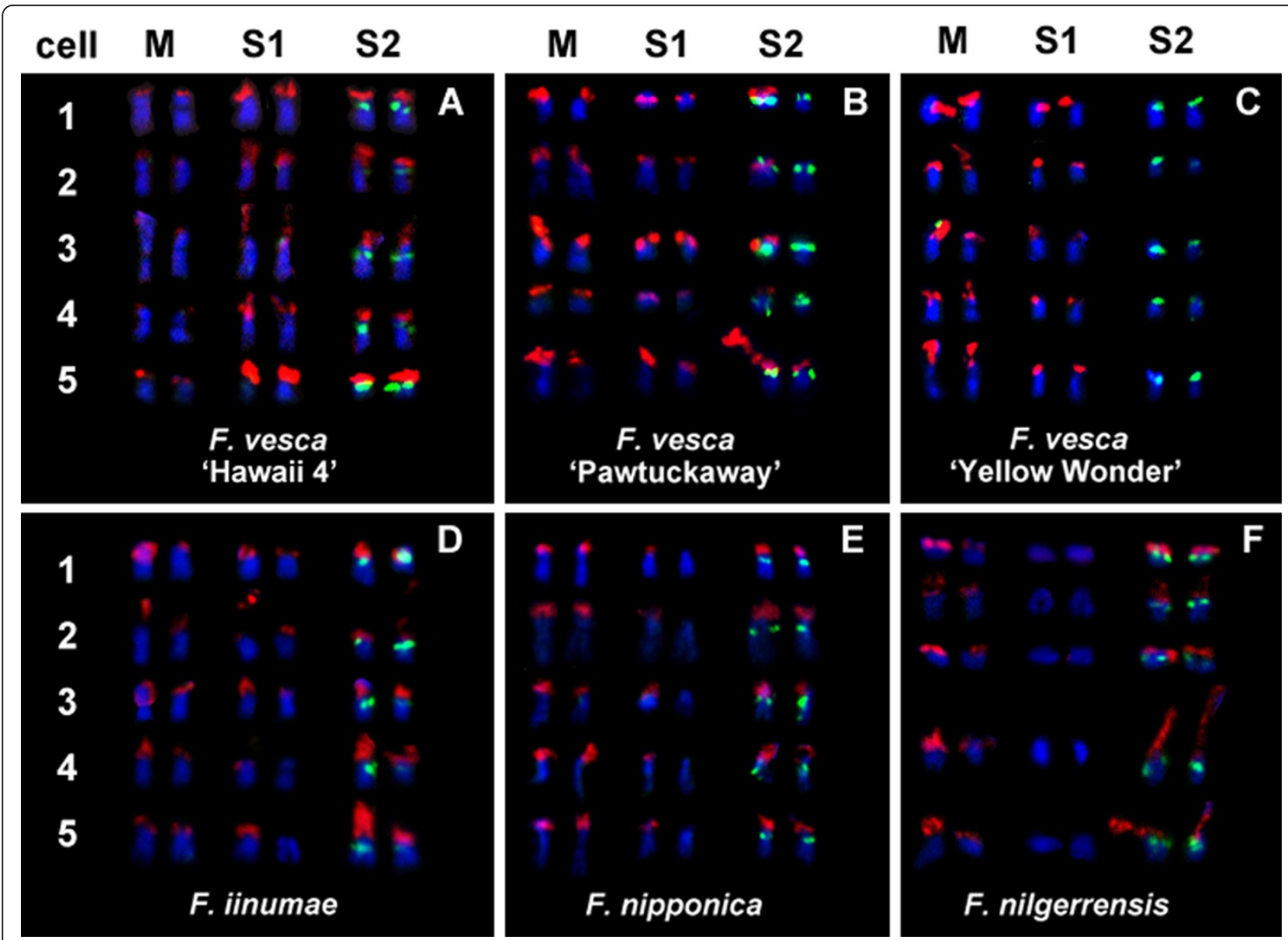

Figure 2 Variable distribution patterns of 5S (green) and 25S (red) rDNA sites among diploid Fragaria genotypes. Five cells (numbered 1-5) are selected from each of six diploid accessions, which show divergent distribution patterns of rDNA sites. Only chromosomes displaying (or "expected" to display) rDNA FISH signals are shown here (M: the medium-sized pair "single-marked" by 25 S rDNA signals; S1: the small-sized pair "single-marked" by 25S rDNA signals; S2: the small-sized pair "double-marked" by both 25S and 5 S rDNA signals in the typical pattern). The pattern represented by $F$. vesca 'Hawaii 4 ' here $(\mathbf{A})$ is the typical one $(6=2 \mathrm{M}+2 \mathrm{~S} 1+2 \mathrm{~S} 2)$ shared by most diploid Fragaria taxa, while distinctly divergent patterns are observed in very a few accessions shown in $\mathbf{B} .5=2 \mathrm{M}+2 \mathrm{~S} 1+1 \mathrm{~S} 2$ with an exception as $6=2 \mathrm{M}+2 \mathrm{~S} 1+2 \mathrm{~S} 2 ; \mathbf{C} .4=2 \mathrm{M}+2 \mathrm{~S} 1$; D. $6=2 \mathrm{M}+2 \mathrm{~S} 1+2 \mathrm{~S} 2$ with an exception as $5=2 \mathrm{M}+1 \mathrm{~S} 1+2 \mathrm{~S} 2 ; \mathbf{E} .5=2 \mathrm{M}+1 \mathrm{~S} 1+2 \mathrm{~S} 2 ; \mathbf{F} .4=2 \mathrm{M}+2 \mathrm{~S} 2$. Within each of most accessions, the distribution pattern among cells is consistent, except for $F$. vesca 'Pawtuckaway' and F. iinumae. In F. vesca 'Pawtuckaway' (B), the S2 pair displays only one $25 \mathrm{~S}$ rDNA signal in cells 1 to 4 but two signals in cell 5. In F. iinumae (D), the S1 pair exhibits two distinct $25 \mathrm{~S}$ rDNA signals in cells 1 to 3 , one distinct and one weak signal in cell 4 , and only one signal in cell 5 .

In the hexaploid species $F$. moschata, two accessions (CFRA 157 and CFRA 376) were examined. Although eighteen $25 \mathrm{~S}$ rDNA sites would be expected as a multiple of three times the number seen in most diploids, only seventeen (in CFRA 376, Figure 3F) or sixteen (in CFRA 157, Figure 3E) were detected. Six 5S rDNA sites were found as anticipated in both accessions, but one of them was not co-localized with a $25 \mathrm{~S}$ rDNA site, and one pair of $5 \mathrm{~S}$ sites was always much larger and more intensive than the other two pairs in both accessions.

We investigated seven octoploids that represent three subspecies of $F$. chiloensis and three subspecies of $F$. virginiana, and found that each of the octoploid taxa shared common $5 \mathrm{~S}$ and $25 \mathrm{~S}$ rDNA site numbers, which were two and ten, respectively (only data for two representative taxa are shown here, in Figures $3 \mathrm{G}$ and $3 \mathrm{H}$ ). These numbers for both $5 \mathrm{~S}$ and $25 \mathrm{~S}$ rDNA sites were much less than the anticipated multiples (eight and twenty-four, respectively) of those in most diploids. In addition, no double-marked chromosomes were observed.

A wild genotype (CFRA 110) in F. virginiana subsp. platypetala was found to be a decaploid by chromosome counting [7]. Our work on the same accession confirmed the ploidy characterization of CFRA 110 by showing 70 chromosomes in a mitotic spread. FISH study detected four $5 \mathrm{~S}$ and fifteen $25 \mathrm{~S}$ rDNA sites distributed over 18 chromosomes, of which one was 


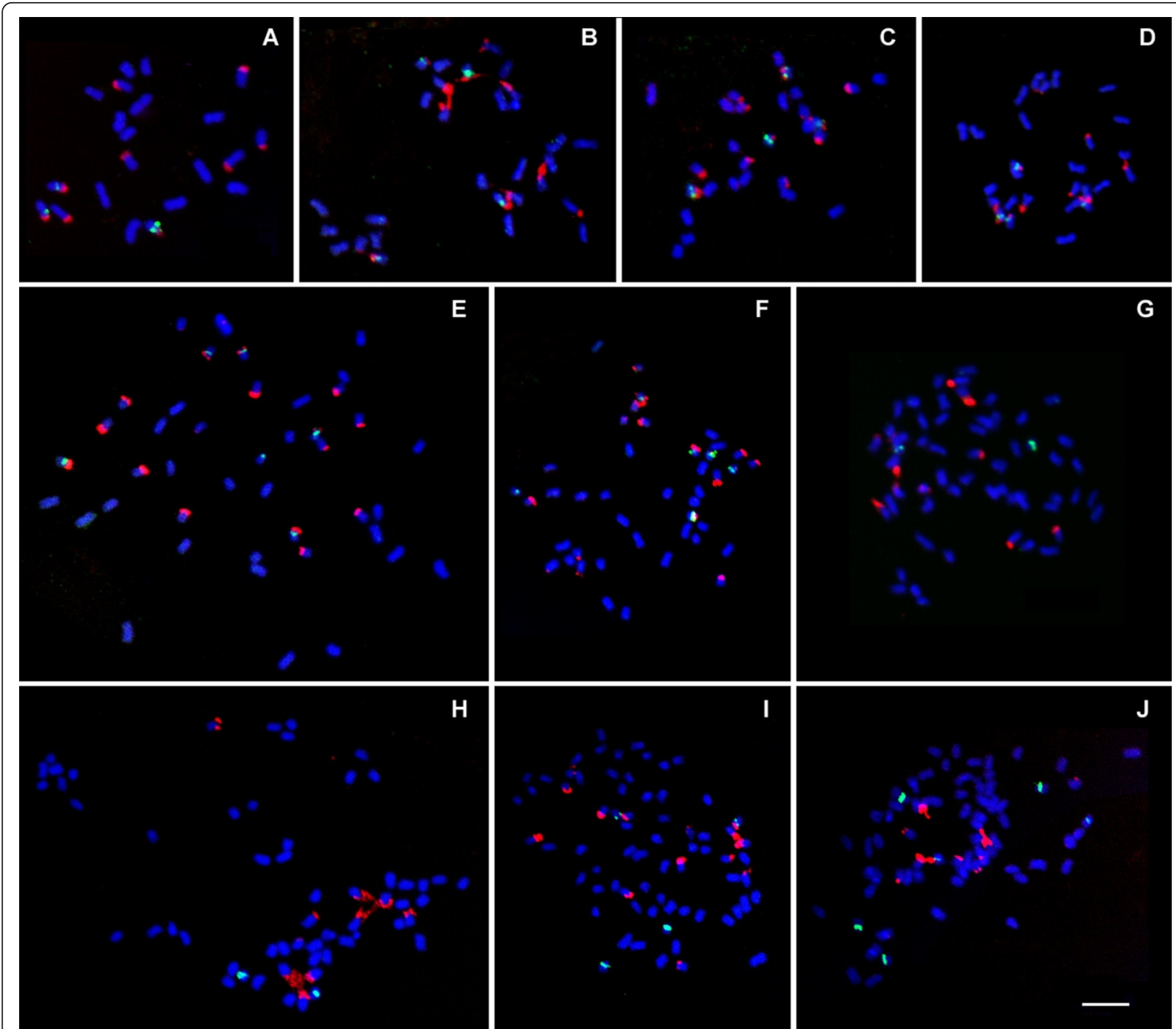

Figure 3 FISH on polyploid Fragaria genotypes with $5 S$ (green signals) and 25 S (red signals) rDNA probes. A: $F . \times b i f e r a ~ ' G S 104^{\prime}(2 n=3 x$ $=21) ;$ B: F. corymbosa (CFRA 1911, $2 n=4 x=28) ; C$ : F. gracilis 'GS31' $(2 n=4 x=28) ;$ D: F. tibetica 'GS28' $(2 n=4 x=28)$; E: F. moschata (CFRA 157, $2 n=6 x=42) ; \mathbf{F}:$ F. moschata (CFRA 376, $2 n=6 x=42) ; \mathbf{G}$ : F. chiloensis subsp. lucida (CFRA 1691, $2 n=8 x=56$ ); H: $F$. virginiana subsp. glauca (CFRA 1992, $2 n=8 x=56) ;$ I: F. virginiana subsp. platypetala (CFRA 110, $2 n=10 x=70)$; J: F. iturupensis (CFRA 1841, $2 n=10 x=70)$. Bar $=$ $5 \mu \mathrm{m}$.

double-marked by a $25 \mathrm{~S}$ and a $5 \mathrm{~S}$ rDNA signal (Figure 3I). In F. iturupensis, the other natural decaploid species found so far in this genus, six $5 \mathrm{~S}$ and twelve $25 \mathrm{~S}$ rDNA sites were detected over eighteen chromosomes, and no chromosome was double-marked (Figure 3J). Both decaploids also presented variable signal sizes and intensities among 5S rDNA sites.

\section{Discussion}

Molecular cytogenetic analysis of ribosomal RNA genes by FISH has been performed in many plants, yet studies spanning an extensive polyploid series and encompassing most of the species within a genus are quite rare. In the strawberry genus Fragaria, prior to our initial report on F. vesca subsp. vesca 'Hawaii 4' in Shulaev et al. [28], only one unspecified accession of one diploid species, F. vesca, had been studied [27]. In the present investigation, nine of the 12 known diploid species as well as several polyploid taxa were studied for genomic distribution of rDNA sites. In total, we extended chromosomal localization of both $5 \mathrm{~S}$ and $25 \mathrm{~S}$ rDNA clusters via FISH to 33 accessions representing 25 taxa (species and subspecies), covering ploidy levels from diploid to decaploid. 
In all the Fragaria species and subspecies examined here, the 5S rDNA signals were displayed in proximal regions of chromosome short arms, while the 25S rDNA signals were on terminal chromosomal regions, indicating that the chromosomal positions of rDNA sites are highly conserved across Fragaria. Yet, as detailed below, marked variations in signal intensity were observed among diploid taxa, and intriguing instances and patterns of signal loss were observed, both within and between ploidy levels.

Typical and exceptional distribution patterns of $5 \mathrm{~S}$ and 25S rDNA sites among diploid strawberry species

Among and within diploid taxa, the observation of two $5 \mathrm{~S}$ and six $25 \mathrm{~S}$ rDNA sites by FISH analysis (Figure 1) was generally consistent with previous findings in $F$. vesca $[27,28]$. Thus, at the diploid level, one copy of the basic $(x=7)$ Fragaria genome is typified by the detectable presence of one $5 \mathrm{~S}$ locus and three $25 \mathrm{~S}$ loci, distributed such that one chromosome is "double-marked" by a proximal $5 \mathrm{~S}$ rDNA locus and a terminal $25 \mathrm{~S}$ rDNA locus, and two chromosomes are "single-marked" by terminal 25S rDNA loci (Figure 2A). By reasonable inference from its typicality, the described pattern may represent that of the ancestral Fragaria genome.

Among diploids, the greatest departures from the typical pattern were two distinct instances of rDNA site loss, each involving a different locus. First, absence of the $25 \mathrm{~S}$ rDNA signals from the S1 pair left both accessions of $F$. nilgerrensis with only four $25 \mathrm{~S}$ signals (e.g., CFRA 1358 in Figure 2F). This divergence of $F$. nilgerrensis from the other diploid species contributes to its status as a well-differentiated evolutionary unit, as suggested by the phylogenetic studies of Rousseau-Gueutin et al. [13] and Harrison et al. [30], and also by the sterility of the hybrids resulting from its crosses with other Fragaria species [31]. Second, F. vesca 'Yellow Wonder' also displayed only four $25 \mathrm{~S}$ signals, but the site losses were from the S2 pair (Figure 2C), also making 'Yellow Wonder' distinct among diploid taxa, including the other studied genotypes of $F$. vesca subsp. vesca. Thus, diminution of $25 \mathrm{~S}$ rDNA site number from six to four has occurred at least twice among diploid Fragaria.

Polymorphisms were also detected in size and intensity of $25 \mathrm{~S}$ rDNA FISH signals, which we described as "major" (large and strong) and "minor" (small and weak) signals, between different loci in the various diploid taxa. Yet of the three typically marked chromosome pairs, no one pair had consistently the brightest or least bright $25 \mathrm{~S}$ signals across the diploid genotypes. Thus, in contrast to the conservation of a typical pattern of rDNA site distribution, the allocation pattern of $25 \mathrm{~S}$ rDNA signal intensities among chromosome pairs varied among diploid genotypes to an extent that precluded typification. Furthermore, polymorphism in signal intensity and/or presence versus absence was observed between homologous $25 \mathrm{~S}$ rDNA sites in many diploid genotypes. Signal absences from one but not both members of a typically marked pair occurred in three cases: F. nipponica (Figure 2E), F. iinumae (Figure 2D), and a genotype ('Pawtuckaway') of $F$. vesca subsp. americana (Figure 2B). The latter pattern of variability between homologs was consistently seen on separately prepared slides suggesting that this variability was not due to experimental artifact. Based upon available data, it would be premature to speculate about the possibility that unbalanced signal intensity between homologs is a precursor to eventual locus loss, culminating in a diminution of $25 \mathrm{~S}$ site number from the typical six to four. However, all the variations summarized above indicate that the 25S rDNA arrays in diploid Fragaria exist in a dynamic state.

\section{Characterization of 25S rDNA arrays in diploid strawberries: conservation of site number and chromosomal position vs. dynamics of copy number}

As FISH is considered to be a semi-quantitative technique [32], it is reasonable to expect that size and intensity of hybridization signals is an indicator of targeted sequence copy number. Thus, the polymorphism of $25 \mathrm{~S}$ rDNA signal intensities revealed among diploid Fragaria may imply different repeat copy numbers among different rDNA sites. Loss of $25 \mathrm{~S}$ rDNA signal(s) could be due to a complete elimination of entire sites, or perhaps only to the loss of most copies of $25 \mathrm{~S}$ rDNA repeats at the respective site(s), resulting in a diminished signal or leaving too few repeats to be detected by FISH. Such outcomes could be attributable to spontaneous deletion of an rDNA-containing fragment from the short arm of the chromosome(s) [33], or to unequal crossing over, which could lead to a loss (and/or gain) of repeats from different sites [34].

Any rDNA site is a stretch of DNA with sequence homology to other rDNA sites on other chromosomes [35]. Thus, physical association of rDNA clusters between both homologous and nonhomologous sites is possible, supported by the fact that rDNA-bearing chromosomes appear to be non-randomly associated with each other at mitotic metaphase [36]. It is widely accepted that association of genes with highly repetitive sequences would increase the opportunity for unequal exchanges. The distal chromosomal position of rDNA sites in strawberry may facilitate this association, which could lead to unequal exchanges and rDNA repeat duplications/deletions, and therefore changes (both increases and decreases) in copy number between both homologous and nonhomologous sites. Size polymorphism of the hybridization signals, among and within 
homologous sites could be explained by such events. On the other hand, somatic exchanges taking place between different sites could make homogenization and changes in rDNA copy number occur especially quickly [36]. Therefore, it is reasonable to suggest that the rDNA repeats in strawberry are in a highly dynamic state because of their terminal positions and potentially high degree of association between sites. However, the high conservation in rDNA site number and chromosomal location, despite their apparent high dynamics of copy number among sites, may indicate conserved genome organization among strawberry species, at least for chromosomal segments involving rDNA sites.

When more than one pair of $18 \mathrm{~S}-25 \mathrm{~S}$ rDNA sites is present in the genome, some sites may be inactive [34]. When sites are active, a secondary constriction is typically visible. Once genes are inactivated (silenced), the constriction disappears, even though the sequence is still present and detectable by FISH [37]. In strawberry, satellites have been reported on a small pair of chromosomes in five diploid species in previous karyotype studies $[23,24]$. In our work, one or two satellites and secondary constrictions are sometimes visible in metaphase chromosome preparations in some diploids (Figure 1), and were always associated with a $25 \mathrm{~S}$ rDNA FISH signal, irrespective of signal size. In reports on some plants, active rDNA clusters that can form nucleolar organization regions (NORs) and produce large and intensive FISH signals have been described as major loci, while the ones without transcription activity but are still detectable by FISH as weak signals are described as minor loci (e.g., Hordeum) [38]. So far, whether all or only some of the rDNA sites in strawberry are actively transcribed and form NORs awaits resolution by further work. The terms "major/minor sites" applied in the Results section are not intended to refer to the transcriptional activity of rDNA sites, but only to relative signal brightness.

\section{Proportional increase of rDNA site number in lower (3x -} 6x) polyploid strawberries

The triploid cytotype of the hybrid $F$. xbifera was previously inferred to possess one copy of the F. vesca genome and two copies of the F. viridis genome [12]. Three $5 \mathrm{~S}$ and nine 25S rDNA sites observed in this triploid cytotype constitute simple multiples of both rDNA site numbers in its two diploid progenitors. The one larger and stronger $5 \mathrm{~S}$ rDNA site is probably from $F$. vesca, while the two smaller ones are from $F$. viridis, in consideration of the copy number of subgenomes provided by the two donors.

In three tetraploids, multiples of $5 \mathrm{~S}$ and $25 \mathrm{~S}$ rDNA site numbers (Figure 3B-3D) are increased in proportion to the increase in whole genome copy number (i.e., in comparison to the typical diploids, the tetraploids had twice as many chromosomes and twice as many detected $5 \mathrm{~S}$ and $25 \mathrm{~S}$ rDNA sites). To date, the alternate possibilities of auto- or allo- polyploidy origin have not been resolved in these tetraploids [13]. Various diploid species occurring in respectively overlapping geographical areas have been proposed as putative ancestors. Due to the highly conserved genomic distribution pattern of rDNA sites among diploids, no specific species were identifiable as putative ancestors of the tetraploids based on rDNA-FISH data. However, variable allocation of 25S rDNA signal intensities among loci between these tetraploids at least implies that the diploid ancestry of $F$. corymbosa may be distinct from those of either F. gracilis or F. tibetica. Lundberg et al. [39] suggested that F. corymbosa was an allotetraploid. The size polymorphism of $5 \mathrm{~S}$ rDNA signals in $F$. corymbosa observed in our work is possibly supportive to this hypothesis.

In the hexaploid species F. moschata, six $5 \mathrm{~S}$ and eighteen $25 \mathrm{~S}$ rDNA sites would be expected as three times those in most diploids. In fact, six $5 \mathrm{~S}$ rDNA sites appeared as distinct FISH signals, but one or two fewer signals for $25 \mathrm{~S}$ rDNA sites were shown in, respectively, F. moschata genotypes CFRA 376 and CFRA 157 (Figure $3 \mathrm{E}$ and $3 \mathrm{~F})$. F. moschata was shown to be an allopolyploid and its subgenome donors include $F$. vesca and $F$. viridis, which were suggested by DNA molecular studies $[13,39,40]$. In F. vesca, some genotypes (e.g., 'Yellow Wonder' and 'Pawtuckaway') have fewer 25S rDNA sites than six. Thus, the $25 \mathrm{~S}$ rDNA site number less than eighteen in a hexaploid would not be surprising, if any F. vesca genotype(s) having less than six $25 \mathrm{~S}$ rDNA sites were involved in its origin. Alternatively, one or two rDNA sites could have been diminished or lost by loss of most or all of its repeats during or after the arising of the hexaploid. When Rousseau-Gueutin et al. [13] studied two low-copy gene sequences for the construction of phylogenetic trees of Fragaria species, they linked $F$. moschata to both $F$. vesca and $F$. viridis in the tree based on the sequence analysis of the gene GBSSI-2, but detected no affinity between $F$. moschata and $F$. viridis in the tree from the DHAR gene, for which physical elimination of one homoeologous copy of this gene was proposed to be a possible reason.

In genotype CFRA 157, five of the six 5S rDNA sites are co-localized with $25 \mathrm{~S}$ rDNA sites, which means loss of one $25 \mathrm{~S}$ rDNA site (if the latter hypothesis discussed above is true) has occurred on one of the six "doublemarked" chromosomes and the second one on a "singlemarked" chromosome. These two chromosomes could not be homologs, suggesting that elimination of $25 \mathrm{~S}$ rDNA sites could occur simultaneously on non-homologous chromosomes. Therefore, in species with a high site number, loss of rDNA copies could proceed very 
quickly simply because there are many opportunities for occurrence of this event. This speculation gains support from the cases of octo- and deca-ploid strawberries, in which eight $5 \mathrm{~S}$ and twenty-four $25 \mathrm{~S}$ rDNA sites, and ten $5 \mathrm{~S}$ and thirty $25 \mathrm{~S}$ rDNA sites, respectively, would be expected but much less are actually observed.

\section{Remarkable rDNA site number reduction in octoploid strawberries}

Each of the two wild octoploid species includes multiple subspecies. In this work, we examined three subspecies of $F$. chiloensis and of $F$. virginiana, respectively. Numbers of $5 \mathrm{~S}$ and $25 \mathrm{~S}$ rDNA sites are consistent among all these subspecies, and a strong reduction in rDNA site number for both kinds of rDNA was observed as compared with proportionate multiples of the typical diploid numbers. The strong reduction in rDNA site number might be attributable to two factors. First, more than a half of the rDNA sites inherited from the lower-ploidy ancestors might have failed to participate in associations occurring among other rDNA-bearing chromosomes, where homogenization through unequal crossing-over and gene conversion could have maintained homology of their DNA sequences and therefore their transcriptional function. Thus, susceptibility to loss of some rDNA arrays may be due simply to the high initial number of rDNA sites. Though rDNA site number is expected to be correlated with genome size, perhaps only a restricted number of rDNA sites under a certain threshold could be associated together and be maintained in homology, and this low number might be sufficient to support normal cellular activity. Thus, extra sites beyond that restricted or necessary number would suffer accumulation of mutations from lack of homogenization forces, and be subject to elimination.

A second possibility is nucleolar dominance, as originally described by Navashin [41] in some species of Crepis. This phenomenon occasionally occurs in natural allopolyploids as well as synthetic interspecific hybrids [42], which show exclusive transcriptional activity of genes encoding $18 \mathrm{~S}, 5.8 \mathrm{~S}$, and $25 \mathrm{~S}$ rRNA that belong to one of the parental genomes with concurrent lack of expression of rDNA from the other parental genome [43]. However, how fast one of the parental rDNA repeat types may be removed from the hybrid genome and by what evolutionary forces is currently unresolved. If nucleolar dominance also occurs in strawberry, loss of rDNA sites could be explained as occurring after loss of the transcriptional activity of these sites.

As an explanation for rDNA site loss, the hypothesis based on nucleolar dominance could be integrated with that of high initial copy number if association of rDNA sites is demonstrated to occur only between those derived from a subset of the diploid ancestors. Although genome composition of octoploid strawberries has not been fully elucidated [44], putative subgenome donors including ancestors of $F$. vesca and $F$. iinumae have been strongly supported by phylogenetic analysis on DNA sequence data of multiple nuclear genes [1,13], whereas in the phylogenetic tree constructed on nuclear ITS sequences [45], F. iinumae is not clustered with any octoploids but is a sister species to all the others. As nuclear ITS is included in the $45 \mathrm{~S}$ rDNA unit, it is reasonable to speculate that rDNA site loss could be subgenome-specific and that rDNA repeats from the ancestral F. iinumae subgenome(s) were lost during or after the establishment of the ancestral octoploid(s).

Davis et al. [46] noticed the evident diminution of genome size by $12 \%$ to $16 \%$ in two octoploid cultivars as compared with an expectation of four times the size of a diploid genome. This diminished size could be due to events, such as losses of DNA segments, that occurred during or after the origination of the octoploids [46]. The marked loss of rDNA sites in octoploids could have been a part of a broader, generalized loss of DNA segments, or could have occurred via a separate and distinct mechanism.

\section{Origins of higher ploidy strawberries}

Identical site numbers of both $5 \mathrm{~S}$ and $25 \mathrm{~S}$ rDNA among all the octoploid subspecies of $F$. chiloensis and F. virginiana suggest that the wild octoploid species are closely related and very likely share a common genome composition or even have a common ancestor, as proposed by phylogenetic analysis based on different DNA sequences [13,30,45]. Moreover, conservation of $5 \mathrm{~S}$ and 25S rDNA site numbers among the octoploid species and subspecies suggests that site loss to observed levels may have been an early event, preceding the divergence of the various octoploid taxa from a common octoploid ancestor. The origin of F. moschata may have followed an independent and perhaps more recent evolutionary pathway as compared with the octoploid lineage(s), given that F. moschata still "maintains" most of its rDNA sites.

The presence of four $5 \mathrm{~S}$ and fifteen $25 \mathrm{~S}$ rDNA sites suggests that the decaploid cytotype for CFRA 110 of the F. virginiana subsp. platypetala originated from doubling of an interspecific hybrid between an octoploid and a diploid species, which are probably $F$. virginiana and an American subspecies of $F$. vesca, respectively, due to the North American geographic collection site of CFRA 110. Thus, this decaploid cytotype could be comprised of two $5 \mathrm{~S}$ and five $25 \mathrm{~S}$ rDNA sites from the $F$. vesca progenitor, and two $5 \mathrm{~S}$ and ten $25 \mathrm{~S}$ rDNA sites from the octoploid progenitor. Contrastingly, the site numbers of six for $5 \mathrm{~S}$ and twelve for 25S rDNA in decaploid F. iturupensis do not fit an origination model 
involving a simple combination of an octoploid and a diploid. In such an origin, the decaploid would be expected to have fewer (four) $5 \mathrm{~S}$ sites and more (15 or 16) $25 \mathrm{~S}$ sites, as seen in decaploid CFRA 110. Instead, the rDNA site numbers in F. iturupensis imply a different and probably more complex origin of this decaploid species as compared with CFRA 110.

\section{Identification of individual chromosomes by rDNA markers}

Due to the extremely small size (i.e., 0.61-1.85 $\mu \mathrm{m}$ for strawberry) [25] and morphologically minimal differentiation of Fragaria chromosomes, chromosome-specific markers provided by FISH are needed for the identification of individual chromosomes, and are critical for tracking homo- or homoeo-logous chromosomes among species and in polyploids.

A previous rDNA-FISH technique performed on $F$. vesca enabled the construction of a karyotype with three pairs of marked chromosomes in diploid strawberry [27]. Confirmatory results were obtained in our lab recently on F. vesca 'Hawaii 4' [28]. For most accessions of $F$. vesca, our data presented here are congruent with the two previous studies. Among the three pairs of chromosomes with rDNA markers, one pair is double marked by $25 \mathrm{~S}$ and $5 \mathrm{~S}$ rDNA, and the other two single marked pairs can be distinguished by their different size and/or signal intensities of $25 \mathrm{~S}$ sites they bear. The other eight chromosomes in a diploid complement are still challenging for even matching of homologs, except for the largest pair, which can be grouped by its size in most cells. To date, various genomic resources for $F$. vesca including a fosmid library [47], mapped and annotated fosmid clones [10], a BAC library [48], and the draft 'Hawaii 4' genome [28] have been established. Assembly has been anchored to the genetic linkage map into seven pseudochromosomes. These all give good opportunities for developing new, chromosome-specific probes that can expand the scope of karyotypic resolution in Fragaria.

We established several fosmid clones for identification of more individual chromosomes besides the rDNA marked ones in $F$. vesca (unpublished data). A comprehensive molecular karyotype in strawberry could be constructed. By finding sequence homology between $25 \mathrm{~S}$ and $5 \mathrm{~S}$ rDNA probes used for chromosome identification and scaffolds mapped to the pseudochromosomes of the 'Hawaii 4' linkage map, the chromosome pair double marked by $25 \mathrm{~S}$ and $5 \mathrm{~S}$ rDNA sites and the other small chromosome pair single marked by $25 \mathrm{~S}$ rDNA signals correspond to pseudochromosome VII and pseudochromosome VI, respectively [28]. As additional probes are developed, the seven linkage groups or pseudochromosomes will be assigned to each specific chromosome so that any sequences of interest defined in a certain pseudochromosome could be verified cytologically along real chromosomes with the assistance of chromosomespecific landmarks in the comprehensive molecular karyotype.

\section{rDNA site numbers in the Rosaceae family}

Physical mapping of rDNA sites by FISH has been performed in several genera of the Rosaceae family, but very few species have been examined within each of these genera. In overview, the number of detected $25 \mathrm{~S}$ rDNA sites in diploid rosaceous species has been either two (in Rosa and Rubus parvifolius) [49-52], four [49], or six (in Prunus) [53-55]. Apple (Malus x domestica), in which a relatively recent genome-wide duplication is indicated [56], has a distinctively high chromosome number of $2 n=34$ in Rosaceae, and eight 25S rDNA sites were observed in it [57]. For $5 \mathrm{~S}$ rDNA, a constant number of two for diploids has been observed in most of these genera except for Prunus [53,54] and Rosa $[50,52]$, in which four sites have been found. In terms of chromosome position, all the rosaceous species including Fragaria exhibit a similar distribution pattern, in which $25 \mathrm{~S}$ rDNA repeats are clustered at terminal regions while 5S rDNA sites are in interstitial and proximal regions of chromosomes. However, "double-marking" by both $5 \mathrm{~S}$ and $25 \mathrm{~S}$ rDNA as seen in Fragaria was only reported for diploid Prunus subhirtella [54] and a pentaploid Rosa canina [50]. Comparative molecular cytogenetic analysis in the Rosaceae will benefit from the development of additional probes targeting conserved sequence sites at multiple chromosomal locations.

\section{Conclusions}

This report describes the first molecular cytological study of comparative genome organization in Fragaria, and reveals the extent to which the genomic distribution of rDNA sites is conserved among and within species and ploidy levels, as well as dynamics of $25 \mathrm{~S}$ rDNA repeats, in this economically important genus. Per basic genome copy, one proximal $5 \mathrm{~S}$ and three terminal $25 \mathrm{~S}$ rDNA loci were largely but not uniformly conserved in diploids $(2 x)$ and lower polyploids $(3 x, 4 x$ and $6 x$ ), but a marked reduction in site number was seen in higher polyploids ( $8 x$ and $10 x$ ). Based upon shared genomic distribution patterns of rDNA sites, a common origin of the Fragaria octoploids is suggested; however, the distinctly different patterns seen in the two recently identified decaploids suggest that these originated independently. In the Rosaceae family, Fragaria was the first genus in which a systematic molecular cytogenetic study has been done, thereby providing a comparator for genomic studies in other rosaceous species that 
could, for instance, reveal common or differing trends in rDNA locus evolution following polyploidy.

\section{Methods}

\section{Plant material}

Twenty-five taxa (species and subspecies) belonging to Fragaria were sampled (Table 1). These included 12 diploid taxa, a triploid cytotype of $F$. $\times$ bifera, three tetraploid species, hexaploid $F$. moschata, seven octoploid taxa, and two decaploids. In total, 33 genotypes belonging to 17 Fragaria species were examined. The geographic distributions of Fragaria are described in Folta and Davis [1] and Hummer et al. [58].

\section{DNA isolation and probe preparation}

Total genomic DNA was isolated from $0.1 \mathrm{~g}$ unexpanded leaf tissue using a modified CTAB protocol [59]. The primers for PCR amplification of 25S rDNA were designed based on 25S rDNA from Arabidopsis thaliana [60], and their sequences were: 25SF - 5'ACGGACCAAGGAGTCTGACATG; and 25SR - 5'CGCTTTCAC GGTTCGTATTCG. Using genomic DNA of $F$. vesca 'Yellow Wonder' as a template, PCR was performed with an initial denaturation at $94^{\circ} \mathrm{C}$ for $3 \mathrm{~min}$, followed by 30 cycles of $94^{\circ} \mathrm{C}$ for $30 \mathrm{sec}, 55^{\circ} \mathrm{C}$ for $20 \mathrm{sec}$, and $72^{\circ}$ $\mathrm{C}$ for $2 \mathrm{~min}$, followed by a $10-\mathrm{min} 72^{\circ} \mathrm{C}$ final extension. Products were purified by ethanol precipitation and labeled by a nick-translation reaction using biotin-16dUTP (Roche Diagnostics, Indianapolis, Indiana). The $5 \mathrm{~S}$ rDNA primers were as in Brown and Carlson [61] with modifications based on the $5 \mathrm{~S}$ rDNA sequence from strawberry of $F$. vesca 'Hawaii 4' [28], and their sequences were: 5SP1 - 5'GAGGGATGCAACACGAGGCC; and 5SP2 - 5'CGGATGCGATCATACCAGCA. The labeling reaction was performed by PCR using template DNA from $F$. vesca 'Yellow Wonder', and dNTPs mixed with DIG-11-dUTP (Roche Diagnostics, Indianapolis, Indiana). The reaction was initially denatured at $94^{\circ} \mathrm{C}$ for $3 \mathrm{~min}$, then subjected to 30 cycles of $94^{\circ} \mathrm{C}$ for $30 \mathrm{sec}, 50^{\circ} \mathrm{C}$ for $20 \mathrm{sec}$, and $72^{\circ} \mathrm{C}$ for $1 \mathrm{~min}$, followed by a $10-\mathrm{min} 72^{\circ} \mathrm{C}$ final extension.

\section{Chromosome preparation and Fluorescence in situ hybridization}

Pretreatment of strawberry root tips was performed as described by Nathewet et al. [25]. Then the root tips were rinsed briefly in $0.075 \mathrm{M} \mathrm{KCl}$ and fixed in 3:1 methanol:acetic acid at $4^{\circ} \mathrm{C}$ for at least $24 \mathrm{hrs}$. Fixed root tips were digested in 2\% Cellulase 'Onozuka' RS (Yakult Honsha, Tokyo, Japan) and 0.05\% Macerozyme R-10 (Yakult Honsha, Tokyo, Japan) at $37^{\circ} \mathrm{C}$ for $20 \mathrm{~min}$ and transferred to $0.075 \mathrm{M} \mathrm{KCl}$ for $10 \mathrm{~min}$. Then the root tips were fixed in 3:1 methanol:acetic acid at $4^{\circ} \mathrm{C}$. Chromosome spreads were made by the smearing method as described by Liu et al. [18], and slides were stored at $-80^{\circ} \mathrm{C}$ until FISH analysis. FISH experiments were carried out with some modifications of the procedure of Liu et al. [62]. Briefly, slides were pretreated using RNase (100 $\mathrm{ng} / \mathrm{ml}$ in $2 \mathrm{xSSC}$ ) and pepsin $(0.01 \%$ in $10 \mathrm{mM} \mathrm{HCl})$, then denatured in $70 \%$ formamide for $3 \mathrm{~min}$ at $80^{\circ} \mathrm{C}$. $25 \mathrm{~S}$ and $5 \mathrm{~S} \mathrm{rDNA}$ probes in $2 x S S C, 50 \%$ deionized formamide, and $10 \%$ dextran sulphate were denatured for $8 \mathrm{~min}$ at $90^{\circ} \mathrm{C}$, then applied to the denatured slides and hybridized overnight at $37^{\circ} \mathrm{C}$. After post-hybridization washes, signals were detected using streptavidin-Cy3 (Sigma) and anti-DIG-FITC (Roche Diagnostics, Indianapolis, Indiana). Slides were mounted and counterstained in Vectashield (Vector Laboratories) containing $2 \mu \mathrm{g} / \mathrm{ml}$ 4',6-diamidino-2-phenylindole (DAPI). Photographs were taken with a ZEISS Axioplan 2 Imaging fluorescence microscope equipped with AxioCam MRm CCD camera (Carl Zeiss, Jena, Germany) and AxioVision 4.8.1 software (Carl Zeiss, Jena, Germany). The images were analyzed with Adobe ${ }^{\circledR}$ Photoshop ${ }^{\circledR}$ CS3 and treated for color contrast and uniform brightness only. At least 5 mitotic metaphase complements per accession were scored.

\section{Acknowledgements and funding}

The authors thank Dr. Kim Hummer (USDA ARS National Clonal Germplasm Repository, Corvallis, Oregon) for her critical review of this manuscript, Melanie E Shields for her editorial assistance, and Elizabeth Poulsen for her preliminary exploration of FISH protocol in strawberry. Support for this research has come from USDA-CSREES NRI Plant Genome Grant 2008-3530004411. Partial funding was provided by the New Hampshire Agricultural Experiment Station. This is Scientific Contribution Number 2460.

\section{Authors' contributions}

$\mathrm{BL}$ designed and performed the research, and drafted the manuscript. TMD conceived of the study and helped to draft the manuscript. Both authors read and approved the final manuscript.

\section{Authors' information}

Both authors are at Department of Biological Sciences, University of New Hampshire, Durham, NH 03824, USA.

Received: 27 August 2011 Accepted: 10 November 2011 Published: 10 November 2011

References

1. Folta KM, Davis TM: Strawberry genes and genomics. Crit Rev Plant Sci 2006, 25:399-415.

2. Staudt G: Strawberry biogeography, genetics and systematics. Acta Hort 2009, 842:71-84.

3. Ichijima K: Cytological and genetic studies on Fragaria. Genetics 1926, 11:590-604.

4. Longley AE: Chromosomes and their significance in strawberry classification. J Agri Res 1926, 15:559-568.

5. Hummer KE, Nathewet $P$, Yanagi T: Decaploidy in Fragaria iturupensis (Rosaceae). Am J Bot 2009, 96:713-716.

6. Staudt G: Fragaria iturupensis, eine neue Erdbeerart aus Ostasien. Willdenowia 1973, 7:101-104.

7. Nathewet $P$, Hummer KE, Yanagi T, Iwatsubo $Y$, Sone K: Karyotype analysis in octoploid and decaploid wild strawberries in Fragaria (Rosaceae). Cytologia 2010, 75:277-288. 
8. Darrow GM: The strawberry: History, Breeding and Physiology. New York: Holt, Rinehart and Winston; 1966.

9. Hummer KE, Hancock JF: Strawberry genomics: botanical history, cultivation, traditional breeding, and new technologies. In Genetics and Genomics of Rosaceae. Edited by: Folta KM, Gardiner SE. New York: Springer; 2009:413-435.

10. Davis TM, Shields ME, Zhang Q, Tombolato-Terzić D, Bennetzen JL, Pontaroli AC, Wang H, Yao Q, SanMiguel P, Folta KM: An examination of targeted gene neighborhoods in strawberry. BMC Plant Biology 2010, 10:81-112

11. Staudt G: Systematics and geographic distribution of the American strawberry species: taxonomic studies in the genus Fragaria (Rosaceae: Potentilleae). University of California Publications in Botany, Berkeley; 199981.

12. Staudt G, DiMeglio LM, Davis TM, Gerstberger P: Fragaria $\times$ bifera Duch.: Origin and taxonomy. Bot Jahrb Syst 2003, 125:53-72.

13. Rousseau-Gueutin M, Gaston A, Ainouche A, Ainouche ML, Olbricht K, Staudt G, Richard L, Benoyes-Rothan B: Tracking the evolutionary history of polyploidy in Fragaria L. (strawberry): new insights from phylogenetic analysis of low-copy nuclear genes. Mol Phylogenet Evol 2009, 51:515-530.

14. Rayburn AL, Gill BS: Use of biotin-labeled probes to map specific DNA sequences on wheat chromosomes. J Hered 1985, 76:78-81.

15. Jiang J, Gill BS: Nonisotopic in situ hybridization and plant genome mapping: the first 10 years. Genome 1994, 37:717-725.

16. Jiang J, Gill BS: Current status and the future of fluorescence in situ hybridization (FISH) in plant genome research. Genome 2006, 49:1057-1068.

17. Kato A, Lamb JC, Birchler JA: Chromosome painting using repetitive DNA sequences as probes for somatic chromosome identification in maize. Proc Natl Acad Sci USA 2004, 101:13554-13559.

18. Liu B, Chen C, Li X, Chen R, Song W: Physical mapping of $45 S$ rDNA to metaphase chromosomes in 30 taxonomically diverse plant species. $J$ Hortic Sci Biotech 2005, 80:287-290.

19. Maluszynska J, Heslop-Harrison JS: Molecular cytogenetics of the genus Arabidopsis: in situ localization of rDNA sites, chromosome numbers and diversity in centromeric heterochromatin. Ann Bot 1993, 71:479-484.

20. Sumner AT: Nucleolar organizers (NORs). In Chromosome Banding. Edited by: Sumner A. London: Unwin Hyman Ltd; 1990:187-205.

21. Pederson T, Politz JC: The nucleolus and the four ribonucleoproteins of translation. J Cell Biol 2000, 148:1091-1095.

22. Heslop-Harrison JS: Comparative genome organization in plants: from sequence and markers to chromatin and chromosomes. Plant Cell 2000, 12:617-635.

23. Iwatsubo $Y$, Naruhashi N: Karyotypes of three species of Fragaria (Rosaceae). Cytologia 1989, 54:493-497.

24. Iwatsubo $\mathrm{Y}$, Naruhashi $\mathrm{N}$ : Karyotypes of Fragaria nubicola and $F$. daltoniana. Cytologia 1991, 56:453-457.

25. Nathewet $P$, Yanagi T, Hummer KE, Iwatsubo Y, Sone K: Karyotype analysis in wild diploid, tetraploid and hexaploid strawberries, Fragaria (Rosaceae). Cytologia 2009, 74:55-364.

26. Nathewet $\mathrm{P}$, Yanagi T, Iwastubo $\mathrm{Y}$, Sone $\mathrm{K}$, Takamura $\mathrm{T}$, Okuda N: Improvement of staining method for observation of mitotic chromosomes in octoploid strawberry plant. Sci Hortic-Amsterdam 2009, 120:431-435.

27. Lim KY: Karyotype and ribosomal gene mapping in Fragaria vesca L. Acta Hort 2004, 649:103-106.

28. Shulaev V, Sargent DJ, Crowhurst RN, Mockler TC, Folkerts O, Delcher AL, Jaiswal P, Mockaitis K, Liston A, Mane SP, Burns P, Davis TM, Slovin JP, Bassil N, Hellens RP, Evans C, Harkins T, Kodira C, Desany B, Crasta OR, Jensen RV, Allan AC, Michael TP, Setubal JC, Celton J, Jasper D, Rees G, Williams KP, Holt SH, Ruiz Rojas Juan Jairo, Chatterjee M, Liu B, Silva H, Meisel L, Adato A, Filichkin SA, Troggio M, Viola R, Ashman T, Wang H, Dharmawardhana P, Elser J, Raja R, Priest HD, Bryant DW Jr, Fox SE, Givan SA, Wilhelm L, Naithani S, Christoffels A, Salama DY, Carter J, Girona EL, Zdepski A, Wang W, Kerstetter RA, Schwab W, Korban SS, Davik J, Monfort A, Denoyes-Rothan B, Arús P, Mittler R, Flinn B, Aharoni A, Bennetzen JB, Salzberg SL, Dickerman AW, Velasco R, Borodovsky M, Richard E, Veilleux RE, Folta KM: The genome of woodland strawberry (Fragaria vesca). Nat Genet 2011, 43:109-118.

29. Shulaev V, Korban SS, Sosinski B, Abbott AG, Aldwinckle HS, Folta KM, lezzoni A, Main D, Arús P, Dandekar AM, Lewers K, Brown SK, Davis TM,
Gardiner SE, Potter D, Veilleux RE: Multiple models for Rosaceae genomics. Plant Physiol 2008, 147:985-1003.

30. Harrison RE, Luby JJ, Furnier GR: Chloroplast DNA restriction fragment variation among strawberry (Fragaria spp.) taxa. J Amer Soc Hort Sci 1997, 122:63-68.

31. Dowrick GJ, Williams H: Species crosses in the genus Fragaria John Innes Horticultural Institution; 1959, 9-10.

32. Maluszynska J, Heslop-Harrison JS: Physical mapping of rDNA loci in Brassica species. Genome 1993, 36:774-781.

33. Zhang D, Sang T: Physical mapping of ribosomal RNA genes in peonies (Paeonia, Paeoniaceae) by fluorescent in situ hybridization: implications for phylogeny and concerted evolution. Am J Bot 1999, 86:735-740.

34. Weiss-Schneeweiss H, Stuessy TF, Siljak-Yakovlev S, Baeza CM, Parker J: Karyotype evolution in South American species of Hypochaeris (Asteraceae, Lactuceae). Plant Syst Evol 2003, 241:171-184.

35. Thomas HM, Harper JA, Morgan WG: Gross chromosome rearrangements are occurring in an accession of the grass Lolium rigidum. Chromosome Res 2001, 9:585-590.

36. Hanson RE, Islam-Faridi MN, Percival EA, Crane CF, Ji Y, McKnight TD, Stelly DM, Price HJ: Distribution of $5 \mathrm{~S}$ and $18 \mathrm{~S}-28 \mathrm{~S}$ rDNA loci in a tetraploid cotton (Gossypium hirsutum L.) and its putative diploid ancestors. Chromosoma 1996, 105:55-61.

37. Maluszynska J, Hasterok R, Weiss H: rRNA genes - their distribution and activity in plants. In Plant Cytogenetics. Edited by: Maluszynska J. Cieszyn, Poland; 1998:75-95.

38. Taketa S, Harrison GE, Heslop-Harrison JS: Comparative physical mapping of the $5 \mathrm{~S}$ and $18 \mathrm{~S}-25 \mathrm{~S}$ rDNA in nine wild Hordeum species and cytotypes. Theor Appl Genet 1999, 98:1-9.

39. Lundberg M, Eriksson T, Zhang Q, Davis TM: New insights into polyploid evolution in Fragaria (Rosaceae) based on the single/low copy nuclear intergenic region RGA1-Subtilase. Systematics and polyploidy evolution in Potentilleae (Rosaceae) Stockholm University, Stockholm, Sweden; 2011, 1-31, $\mathrm{PhD}$ thesis by Lundberg $\mathrm{M}$.

40. Lin J, Davis TM: S1 analysis of long PCR heteroduplexes: detection of chloroplast indel polymorphisms in Fragaria. Theor Appl Genet 2000, 101:415-420.

41. Navashin M: Chromosome alterations caused by hybridization and their bearing upon certain genetic problems. Cytologia 1934, 5:169-203.

42. Reeder RH: Mechanisms of nucleolar dominance in animals and plants. J Cell Biol 1985, 101:2013-2016.

43. Pikaard CS: The epigenetics of nucleolar dominance. Trends Genet 2000, 16:495-500.

44. Davis TM, Shields ME, Zhang Q, Poulsen EG, Folta KM, Bennetzen UL, San Miguel P: The strawberry genome is coming into view. In Proceedings of the VIth International Strawberry Symposium: 3-7 March 2008; Huelva, Spain. Volume 842. Edited by: Lopez-Medina J. Acta Hort; 2009:533-536.

45. Potter D, Luby JJ, Harrison RE: Phylogenetic relationships among species of Fragaria (Rosaceae) inferred from non-coding nuclear and chloroplast DNA sequences. Syst Bot 2000, 25:337-348.

46. Davis TM, Denoyes-Rothan B, Lerceteau-Köhler E: Strawberry. In Genome Mapping and Molecular Breeding in Plants. Volumn 4 Fruits and Nuts. Edited by: Kole C. Heidelberg: Springer-Verlag Berlin; 2007:189-205.

47. Pontaroli AC, Rogers RL, Zhang Q, Shields ME, Davis TM, Folta KM, SanMiguel P, Bennetzen $\mathrm{JL}$ : Gene content and distribution in the nuclear genome of Fragaria vesca. The Plant Genome 2009, 2:93-101.

48. Bonet J, Girona EL, Sargent DJ, Muñoz-Torres MC, Monfort A, Abbott AG, Arús P, Simpson DW, Davik J: The development and characterization of a bacterial artificial chromosome library for Fragaria vesca. BMC Research Notes 2009, 2:188-192.

49. Fernández-Romero MD, Torres AM, Millán T, Cubero Jl, Cabrera A: Physical mapping of ribosomal DNA on several species of the subgenus Rosa. Theor Appl Genet 2001, 103:835-838.

50. Lim KY, Werlemark G, Matyasek R, Bringloe JB, Sieber V, El Mokadem H, Meynet J, Hemming J, Leitch AR, Roberts AV: Evolutionary implications of permanent odd polyploidy in the stable sexual, pentaploid of Rosa canina L. Heredity 2005, 94:501-506.

51. Ma Y, Islam-Faridi MN, Crane CF, Ji Y, Stelly DM, Price HJ, Byrne DH: In situ hybridization of ribosomal DNA to rose chromosomes. J Hered 1997, 88:158-161. 
52. Mishima M, Ohmido N, Fukui K, Yahara T: Trends in site - number change of rDNA loci during polyploid evolution in Sanguisorba (Rosaceae). Chromosoma 2002, 110:550-558.

53. Corredor E, Román M, García E, Perera E, Arús P, Naranjo T: Physical mapping of rDNA genes establishes the karyotype of almond. Ann Appl Biol 2004, 144:219-222.

54. Maghuly F, Schmoellorl B, Temsch EM, Laimer M: Genome size, karyotyping and FISH physical mapping of $45 \mathrm{~S}$ and $5 \mathrm{~S}$ genes in two cherry rootstocks: Prunus subhirtella and Prunus incisa $\mathrm{x}$ serrula. $J$ Biotechnol 2010, 149:88-94.

55. Yamamoto M, Shimada T, Haji T, Mase N, Sato Y: Physical mapping of the $18 \mathrm{~S}$ ribosomal RNA gene of peach (Prunus persica (L.) Batch) chromosomes by fluorescence in situ hybridization. Breeding Sci 1999, 49:49-51.

56. Velasco R, Zharkikh A, Affourtit J, Dhingra A, Cestaro A, Kalyanaraman , Fontana P, Bhatnagar SK, Troggio M, Pruss D, Salvi S, Pindo M, Baldi P, Castelletti S, Cavaiuolo M, Coppola G, Costa F, Cova V, Dal Ri A, Goremykin V, Komjanc M, Longhi S, Magnago P, Malacarne G, Malnoy M, Micheletti D, Moretto M, Perazzolli M, Si-Ammour A, Vezzulli S, Zini E, Eldredge G, Fitzgerald LM, Gutin N, Lanchbury J, Macalma T, Mitchell JT, Reid J, Wardell B, Kodira C, Chen Z, Desany B, Niazi F, Palmer M, Koepke T, Jiwan D, Schaeffer S, Krishnan V, Wu C, Chu VT, King ST, Vick J, Tao Q, Mraz A, Stormo A, Stormo K, Bogden R, Ederle D, Stella A, Vecchietti A, Kater MM, Masiero S, Lasserre P, Lespinasse Y, Allan AC, Bus V, Chagné D, Crowhurst RN, Gleave AP, Lavezzo E, Fawcett JA, Proost S, Rouzé P, Sterck L, Toppo S, Lazzari B, Hellens RP, Durel C, Gutin A, Bumgarner RE, Gardiner SE, Skolnick M, Egholm M, Van de Peer Y, Salamini F, Viola R: The genome of the domesticated apple (Malus x domestica Borkh.). Nat Genet 2010, 42:833-841.

57. Schuster M, Fuchs J, Schubert I: Cytogenetics in fruit breeding localization of ribosomal RNA genes on chromosomes of apple (Malus $\mathrm{x}$ domestica Borkh.). Theor Appl Genet 94:322-324.

58. Hummer KE, Bassil N, Njuguna W: Fragaria. In Wild Crop Relatives: Genomic and Breeding Resources, Temperate Fruits. Edited by: Kole C. Heidelberg: Springer-Verlag Berlin; 2011:17-44.

59. Orcheski $B B$, Davis TM: An enhanced method for sequence walking and paralog mining: $\mathrm{TOPO}^{\circledR}$ Vector-Ligation PCR. BMC Res Notes 2010, 3:61-66.

60. Unfried I, Gruendler P: Nucleotide sequence of the $5.8 \mathrm{~S}$ and $25 \mathrm{~S}$ rRNA genes and the internal transcribed spacers from Arabidopsis thaliana. Nucleic Acids Res 1990, 18:4011.

61. Brown GR, Carlson JE: Molecular cytogenetics of the genes encoding 18s5.8s-26s rRNA and 5s rRNA in two species of spruce (Picea). Theor Appl Genet 1997, 95:1-9.

62. Liu B, Zhang S, Zhang Y, Lan T, Qi L, Song W: Molecular cytogenetic analysis of four Larix species by bicolor fluorescence in situ hybridization and DAPI banding. Int J Plant Sci 2006, 167:367-372.

doi:10.1186/1471-2229-11-157

Cite this article as: Liu and Davis: Conservation and Loss of Ribosomal RNA Gene Sites in Diploid and Polyploid Fragaria (Rosaceae). BMC Plant Biology 2011 11:157.

\section{Submit your next manuscript to BioMed Central and take full advantage of:}

- Convenient online submission

- Thorough peer review

- No space constraints or color figure charges

- Immediate publication on acceptance

- Inclusion in PubMed, CAS, Scopus and Google Scholar

- Research which is freely available for redistribution

Submit your manuscript at www.biomedcentral.com/submit
Biomed Central 